\title{
Alkaloid Escholidine and Its Interaction with DNA Structures
}

\author{
Petra Jarošová ${ }^{1}$, Pavel Hannig ${ }^{1}$, Kateřina Kolková ${ }^{1}$, Stefania Mazzini ${ }^{2} \mathbb{D}$, Eva Táborská ${ }^{3}$, Raimundo Gargallo ${ }^{4}{ }^{\oplus}$, \\ Gigliola Borgonovo ${ }^{2}$, Roberto Artali ${ }^{5}(\mathbb{D})$ and Petr Táborský ${ }^{1, *(1)}$
}

1 Department of Chemistry, Faculty of Science, Masaryk University, Kamenice 5, 62500 Brno, Czech Republic; petrajarosova1@gmail.com (P.J.); 461195@mail.muni.cz (P.H.); 474269@mail.muni.cz (K.K.)

2 Department of Food, Environmental and Nutritional Sciences (DEFENS), Section of Chemical and Biomolecular Sciences, University of Milan, Via Celoria 2, 20133 Milan, Italy; stefania.mazzini@unimi.it (S.M.); gigliola.borgonovo@unimi.it (G.B.)

3 Department of Biochemistry, Faculty of Medicine, Masaryk University, Kamenice 5, 62500 Brno, Czech Republic; taborska@med.muni.cz

4 Department of Chemical Engineering and Analytical Chemistry, University of Barcelona, Marti i Franquès 1, E-08028 Barcelona, Spain; raimon_gargallo@ub.edu

5 Scientia Advice di Roberto Artali, 20832 Desio, Italy; roberto.artali@scientia-advice.com

* Correspondence: taborak@email.cz

check for updates

Citation: Jarošová, P.; Hannig, P.; Kolková, K.; Mazzini, S.; Táborská, E.; Gargallo, R.; Borgonovo, G.; Artali, R.; Táborský, P. Alkaloid Escholidine and Its Interaction with DNA Structures. Biology 2021, 10, 1225. https:// doi.org/10.3390/biology10121225

Academic Editor: Weiguo Cao

Received: 6 September 2021

Accepted: 20 November 2021

Published: 24 November 2021

Publisher's Note: MDPI stays neutral with regard to jurisdictional claims in published maps and institutional affiliations.

Copyright: (c) 2021 by the authors. Licensee MDPI, Basel, Switzerland. This article is an open access article distributed under the terms and conditions of the Creative Commons Attribution (CC BY) license (https:// creativecommons.org/licenses/by/ $4.0 /)$.
Simple Summary: Escholidine is a rare protoberberine alkaloid present in trace amounts in roots of Eschscholtzia californica and in the aerial parts of Hunnemannia fumariaefolia. Due to the characteristic charged structure, it can interact with various forms of nucleic acids, including non-canonical structures. A series of spectroscopic experiments have shown notable melting stabilization of antiparallel G-quadruplex sequence DL40 induced by escholidine $\left(\Delta \mathrm{T}_{\mathrm{m}}=5.2^{\circ} \mathrm{C}\right)$. Interaction stoichiometry calculated from fluorescence titration curves was estimated to be 4:1 or 5:1 (alkaloid:DNA). Nuclear Magnetic Resonance (NMR) experiments have confirmed that an external loop binding is likely responsible for this stabilization. The three-dimensional model of the complex between escholidine and DL40, obtained as a result of the molecular docking experiment, implies the preferred orientation of escholidine to the quadruplex structure. Since the stabilization of telomeric G-quadruplex structures by small ligands is often used as a strategy in anti-cancer therapy, alkaloid escholidine seems to be an interesting agent from a medicinal point of view.

Abstract: Berberine, the most known quaternary protoberberine alkaloid (QPA), has been reported to inhibit the SIK3 protein connected with breast cancer. Berberine also appears to reduce the bcl-2 and XIAP expression-proteins responsible for the inhibition of apoptosis. As some problems in the therapy with berberine arose, we studied the DNA binding properties of escholidine, another QPA alkaloid. CD, fluorescence, and NMR examined models of i-motif and G-quadruplex sequences present in the n-myc gene and the c-kit gene. We provide evidence that escholidine does not induce stabilization of the i-motif sequences, while the interaction with G-quadruplex structures appears to be more significant.

Keywords: escholidine; G-quadruplex; DNA; cancer; alkaloid; spectroscopy

\section{Introduction}

Quaternary protoberberine alkaloids (QPA) represent a large class of isoquinoline alkaloids [1-4]. They consist of variations of a tetracyclic ring system, a derivate of 5,6dihydrodibenzo[ $[a, g]$ quinolizinium [5-7]. The most famous QPA is berberine, which is used to treat, for example, diabetes and hypercholesterolemia in traditional medicine [8]. Moreover, berberine is examined as a potential treatment for breast cancer. Expression of the gene coding protein SIK3 is connected with breast cancer, and berberine combined with emodin can inhibit this protein [9]. In vivo study proved that berberine reduced bcl-2 and XIAP expression-proteins responsible for inhibition of apoptosis [10]. Other 
studies interested in treating colon cancer [11] demonstrated the positive effect of berberine. However, some berberine properties, as induction of drug resistance, can be a problem for the therapy [8]. The problem could be solved by combining different treatments or finding other alkaloids with similar properties within the class of QPA. A deeper study of developments in cells can be helpful.

Escholidine (Figure 1) is a QPA [12] present in the plant Escholtzia californica [13]. It is used as a sedative and painkiller, especially useful for treating sleep and dream-related disorders served in the form of teas, tinctures, or extracts [14,15]. In the plant other alkaloids are also present, such as californidine and escholtzine, which are the major ones, as well as sanguinarine, sanguirubine, or macarpine [16].<smiles>COc1ccc2c(c1O)C[N+]1(C)CCc3cc4c(cc3C1C2)OCO4</smiles>

Figure 1. Structure of alkaloid escholidine.

Recent studies highlight the potential importance of non-canonical forms of DNA, such as G-quadruplex (G4) or i-motif, in replication, transcription, or translation processes and mRNA splicing [17-19]. Non-canonical DNA structures are characterized by their specific sequence. G-quadruplexes are formed by guanine-rich sequences and stabilized by cations, such as $\mathrm{K}^{+}$or $\mathrm{Na}^{+}$[20]. The i-motif structures are formed by cytosine-rich sequences and are stable at slightly acid $\mathrm{pH}$ values. Both structures are found at the end of telomers and near the promoter region of several oncogenes such as $b c l-2, c-m y c$, VEGF and RET [19].

The elementary unit of G4 is the " $\pi$-stacked" guanine tetrad, also called the G-quartet, which forms an almost planar structure. This tetrad consists of four cyclically arranged guanine bases rotated $90^{\circ}$ and connected by a total of eight Hoogsteen hydrogen bonds linking amino and imino protons of one base to nitrogen N7 and oxygen O6 atoms of the adjacent base, respectively (Figure 2a,b). G-quartets are layered on top of each other in a spatial arrangement. There is a free space in the center of the guanine tetrads, which is filled mainly by univalent alkali metal cations $\left(\mathrm{K}^{+}, \mathrm{Na}^{+}\right)$[21-24].

The G-quadruplex structures can consist of several strands of different molecules or be formed intramolecularly. Figure 2 shows unimolecular (c), bimolecular (d), and tetramolecular (e) type. Furthermore, fibers of the G-quadruplex can be arranged in a variate direction. They can form parallel G-quadruplex, otherwise antiparallel. The most common type, which is present in living cells, is the unimolecular G-quadruplex. There are also hybrid structures containing three fibers in the same direction and one in the opposite direction [25].

The i-motif consists of two parallel duplexes zipped together by the intercalation, cytosines bonds together by three hydrogen bonds (Figure 3). One of the cytosines must be in a protonated form to form hydrogen bonds, hence the reason why i-motifs are so sensitive to $\mathrm{pH}$ [26]. They exist rather in acidic solution [27-29] because at $\mathrm{pH}$ higher than 6.5, approximately, cytosine bases are deprotonated, and hydrogen bonds disappear. The exception is i-motives with a tract length of at least five cytosines, which can also exist in physiological $\mathrm{pH}$ [30]. In addition to $\mathrm{pH}$, the temperature and length, and structure of the loop also affect the stability of i-motif [31,32]. Due to the influence of $\mathrm{pH}$ on its stability, the i-motif structure has not received so much attention in the past because it was assumed that it could not occur in a physiological environment. The interest in i-motif has grown in 
recent years because it has been proved that $i$-motives can occur in vivo and in the presence of an acidic microenvironment in some tumor cells ( $\mathrm{pH}$ of 6.5-6.8) [33-38].

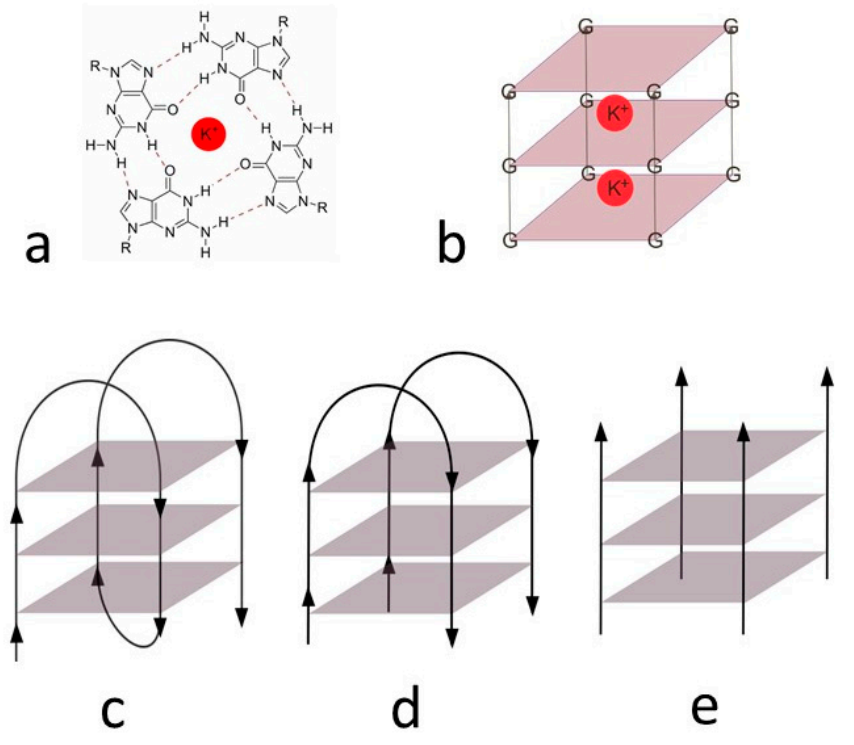

Figure 2. G-tetrad (a) and three-dimensional schematic structure with potassium ions (b), unimolecular (c), bimolecular, (d) tetramolecular, and (e) G-quadruplex.

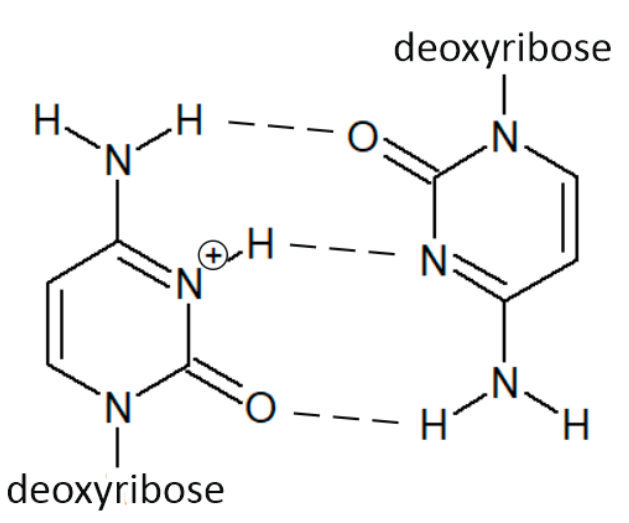

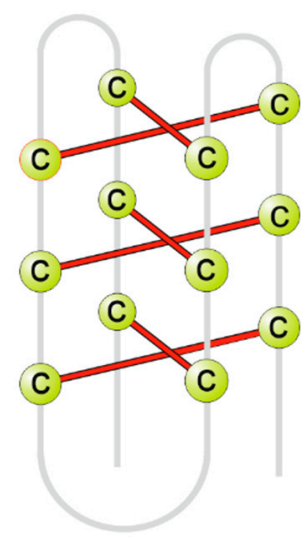

Figure 3. Primary (left) and secondary (right) structure of i-motif.

In this work, we study the influence of alkaloid escholidine on the stability of a set of DNA sequences forming different G-quadruplex and i-motif structures. While increased stability of G-quadruplex:ligand complex over the G-quadruplex alone was proven with many groups of chemicals (protoberberine [39] and benzo[c]phenanthridine [40] alkaloids, antraquinones [41]), increased stability of i-motif with ligand was observed only in several cases [42]. In addition, berberine was found to bind an AT-rich sequence in the minor groove of the double helix [43], while no specific interactions with any C-rich sequence were found [44].

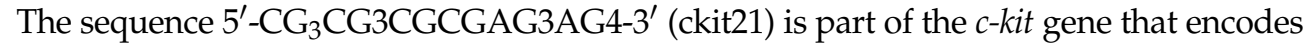
receptor tyrosine kinase. A stable parallel G-quadruplex structure was identified on this sequence in humans, chimpanzees, and rats [45]. Sequence 5'-G ${ }_{3}$ CG3CGCGAG3AG3T-3' (GG1) was prepared by removing the first cytosine and G to T mutation at position 21. A further $\mathrm{G}$ to $\mathrm{T}$ mutation at position 12 was also considered (ckit21T12T21) [46].

The sequence 5'-G2T4G2CAG3T4G2T-3' (DL40) forms a unimolecular antiparallel G-quadruplex, containing two diagonal loops and one reversal loop [46].

The sequence 5'-AC5TGCATCTGCATGC5TC3AC5T-3' (nmyc01), located near the promoter region of the $n$-myc gene, presents an i-motif conformation. An increased presence of 
this $n$-myc gene is associated with an increased incidence of tumors, mainly neuroblastoma. In this work, we studied the interactions of escholidine with this sequence and with the TGCA to TTTT mutated sequences at 13-16 level (nmyc01m) to prevent hairpin structure formation $[47,48]$.

The sequence 5'-C3TA2C3TA2C3TA2C3T-3' (22nt) contains sequence CCCTAA, which frequently occurs in telomeric DNA. In lower eukaryotes presence of G-quadruplexes was confirmed. Telomeres play an important role in cancer; thus are strictly regulated in human cells. Cancer cells often secrete many telomeres leading to cancer growth $[23,49,50]$.

\section{Materials and Methods}

Alkaloids were extracted from plant material in the Department of Biochemistry, Faculty of Science, Masaryk University (Brno, Czech Republic). The oligonucleotides used in this work (Table 1) were purchased as dry samples from Thermo Fisher Scientific (Waltham, MA, USA) at HPLC grade. Other reagents, such as $\mathrm{KH}_{2} \mathrm{PO}, \mathrm{KCl}, \mathrm{NaOH}$, $\mathrm{KOH}$, and $\mathrm{CH}_{3} \mathrm{COONa}$ (all p.a. grade), were purchased from Lach-Ner (Neratovice, Czech Republic).

Table 1. Sequences of measured oligonucleotides.

\begin{tabular}{ccc}
\hline Code & Sequence $\mathbf{( 5}^{\prime}-\mathbf{3}^{\prime}$ ) & Type \\
\hline GG1 & GGGCGGGCGCGAGGGAGGGT & Parallel G-quadruplex [45] (pH 7) \\
DL40 & GGTTTTGGCAGGGTTTTGGT & Antiparallel G-quadruplex [46] (pH 7) \\
nmyc01 & ACCCCCTGCATCTGCATGCCCCCTCCCACCCCCT & i-motif + duplex hairpin [47] (pH 5) \\
nmyc01m & ACCCCCTGCATCTTTTTGCCCCCTCCCACCCCCT & I-motif [47] (pH 5) \\
22nt & CCCTAACCCTAACCCTAACCCT & I-motif [23] (pH 5) \\
\hline
\end{tabular}

\subsection{Melting Experiments}

The melting temperature $\left(\mathrm{T}_{\mathrm{m}}\right)$ of oligonucleotides was determined by CD spectroscopy on a Jasco J815 device. For all measurements, samples were prepared with a final concentration of $2 \mu \mathrm{M}$ oligonucleotide and $8 \mu \mathrm{M}$ alkaloid. G-quadruplexes were prepared in phosphate buffer solution ( $5 \mathrm{mM} \mathrm{KCl}, 10 \mathrm{mM} \mathrm{KH}_{2} \mathrm{PO}_{4} \mathrm{pH}$ 7). The i-motif samples were prepared in acetate buffer $\left(0.2 \mathrm{M} \mathrm{CH}_{3} \mathrm{COONa}\right.$, $\left.\mathrm{pH} 5\right)$.

A magnetic stirrer and temperature sensor were inserted into the cuvette. Spectra of ellipticity dependence on wavelength from 220 to $330 \mathrm{~nm}$ were measured between $20-95{ }^{\circ} \mathrm{C}$ for each sample. The wavelength at which the signal reaches the maximum (nmyc01, nmyc01m, 22nt at $287 \mathrm{~nm}$, DL40 at $291 \mathrm{~nm}$, GG1 at $261 \mathrm{~nm}$ ) was deducted from the measured spectra. During further measurements, ellipticity was measured only at the selected wavelength with $\Delta \mathrm{T}=0.2{ }^{\circ} \mathrm{C}$ with increasing/decreasing temperature $1{ }^{\circ} \mathrm{C} / \mathrm{min}$. The sample was measured in both directions (heating and cooling) to determine the potential presence of hysteresis. The ellipticity/temperature dependence graph has been created from the selected wavelength. From this graph, thermodynamic variables, such as melting temperatures and enthalpy and entropy changes, were calculated using an in-house-made program written in Matlab ${ }^{\circledR}$. The algorithm was based on that which was previously published by Puglisi [51] and Breslauer [52], using a two-state unfolding process and considering the changes in enthalpy and entropy invariable in the temperature range studied. Graphs were smoothed by the Savitzky-Golay function.

\subsection{Fluorescence Titrations}

Alkaloid solution was placed into a cuvette, the concentration of escholidine was $3 \times 10^{-5} \mathrm{~mol} \cdot \mathrm{L}^{-1}$. The solution also contained $\mathrm{KCl}$ at a concentration of $0.005 \mathrm{~mol} \cdot \mathrm{L}^{-1}$ and a buffer of $0.01 \mathrm{~mol} \cdot \mathrm{L}^{-1}$, phosphate buffer $\mathrm{pH} 7$ for structures of G-quadruplex, acetate buffer $\mathrm{pH} 5$ for i-motif structures. A titrating solution of oligonucleotide was prepared and also contained an alkaloid, $\mathrm{KCl}$, and a buffer of the same concentration as in the alkaloid solution, not changing their concentration in the cuvette. 
The fluorescence spectrum of the pure alkaloid solution was measured first. Then, the alkaloid solution was titrated with the oligonucleotide solution, and the fluorescence spectrum was measured after each addition.

All spectra were transferred to the Matlab ${ }^{\circledR}$ program, where they were fitted to curves corresponding to individual stoichiometric ratios using the Equispec function [53]. The best model was selected by the least-squares method to determine the stoichiometric ratio of the DNA:ligand complex, and the association constant $\log \mathrm{K}_{\mathrm{a}}$ was obtained.

\subsection{NMR Spectroscopy}

NMR spectra were recorded on a Bruker AV600 spectrometer operating at a frequency of $600.10 \mathrm{MHz}$, equipped with a $5 \mathrm{~mm}$ TXI inverse probe and $z$-axis gradients. The ${ }^{1} \mathrm{H}$ spectra were acquired at $25^{\circ} \mathrm{C}$. The NMR sample of i-motif oligonucleotides (nmyc01, nmyc01m, and 22nt) was prepared in $\mathrm{H}_{2} \mathrm{O} / \mathrm{D}_{2} \mathrm{O}(9: 1)$ concentration range from 0.4 to $0.9 \mathrm{mM}$ containing sodium phosphate buffer, $\mathrm{pH}$ 5.0. The G-quadruplex DL40 was prepared in $\mathrm{H}_{2} \mathrm{O} / \mathrm{D}_{2} \mathrm{O}$ (9:1) in buffer containing $150 \mathrm{mM} \mathrm{NaCl}$ and sodium phosphate $\mathrm{pH}$ 6.8. The sample of c-kit21was prepared at a concentration of $0.40 \mathrm{mM}$, dissolved in $5 \mathrm{mM} \mathrm{KH}_{2} \mathrm{PO}_{4}$, $20 \mathrm{mM} \mathrm{KCl}, \mathrm{pH}$ 6.9. Moreover, for the NMR studies, also the c-kit21T12T21-mer sequence, $5^{\prime}$ - CGGGCGGGCGCT $^{\mathbf{1 2}}$ AGGGAGGGT ${ }^{21}-3^{\prime}$ was used as the G to T mutation at position 12, and 21 further stabilizes, at low $\mathrm{KCl}$ concentration, the monomeric intramolecular parallel G-quadruplex [54].

The samples were heated to $85^{\circ} \mathrm{C}$ for $1 \mathrm{~min}$ and then cooled at room temperature overnight. The 2D NOESY spectra of DL40 were performed using standard pulse sequences in phase-sensitive mode with 300 ms of mixing time. Raw data were Fourier-transformed after apodization with a $90^{\circ}$-shifted sine-bell-squared function, zero-filling to $2 \mathrm{~K} \times 2 \mathrm{~K}$ real data points, and baseline corrected. The NMR data were processed using TOPSPIN 1.3 and analyzed by the Sparky program (University of California, San Francisco, CA, USA). Small amounts of the escholidine stock solution in DMSO- $d_{6}(52 \mathrm{mM})$ were added at different $\mathrm{R}=(\mathrm{drug}) /(\mathrm{DNA})$ ratios to the oligonucleotide solutions.

\subsection{Molecular Modeling Studies}

We used docking calculations to elucidate interaction model [55]. The starting three-dimensional structure of escholidine was obtained from PubChem (PubChem CID: 102387713) [56], while that of the antiparallel G-quadruplex DL40 was taken from the NMR ensemble deposited in the Protein Data Bank (PDB accession code: 1i34) [46].

Flexible docking calculations at the DL40 target were performed by AutoDock 4.2 [57], using the Lamarckian Genetic Algorithm in combination with a grid-based energy evaluation method was to calculate grid maps $(80 \AA \times 80 \AA \times 80 \AA$ box with a spacing of $0.01 \AA$ ). Gasteiger-Marsili charges [58] were added to the ligand by using AutoDock Toolkit (ADT) [59]. The solvation parameters were added to the system by means of the Addsol utility of AutoDock, and the phosphorus atoms in the G-quadruplex structure were parameterized using the Cornell parameters. The experiment was conducted with an initial population consisting in 100 randomly placed escholidine molecules. The maximum number of energy evaluations was set at 250 with an elitism value of 1 , a mutation rate of 0.02 and a crossover rate of 0.80 . The local search was conducted using 250 independent docking runs using the pseudo-Solis and Wets algorithm, with a maximum of 250 iterations per local search. The docking results were scored by using an in-house version of the simpler intermolecular energy function based on the Weiner force field, and the lowest energy conformations (differing by less than $1.0 \AA$ in positional root-mean-square deviation (rmsd)) were collected.

Molecular graphics and analyses performed with UCSF ChimeraX, developed by the Resource for Biocomputing, Visualization, and Informatics at the University of California, San Francisco, with support from National Institutes of Health R01-GM129325 and the Office of Cyber Infrastructure and Computational Biology, National Institute of Allergy and Infectious Diseases [60]. 


\section{Results and Discussion}

\subsection{Spectra and Meltings}

First, CD spectra of the considered oligonucleotides were measured in the absence and presence of escholidine.

Oligonucleotides 22nt, nmyc 01 , and nmyc $01 \mathrm{~m}$ form i-motif structures at slightly acidic $\mathrm{pH}$ values. Hence, at $\mathrm{pH} 5$ the spectra of the three nucleotides have the same shape with a positive peak around $290 \mathrm{~nm}$ and a smaller negative peak around $260 \mathrm{~nm}$, which are indicative of the formation of i-motif structures. There was no apparent effect of escholidine on the shape and intensity of the spectrum of any of these sequences (Figure 4), indicating that the potential interaction with the drug did not modify the overall i-motif structure.
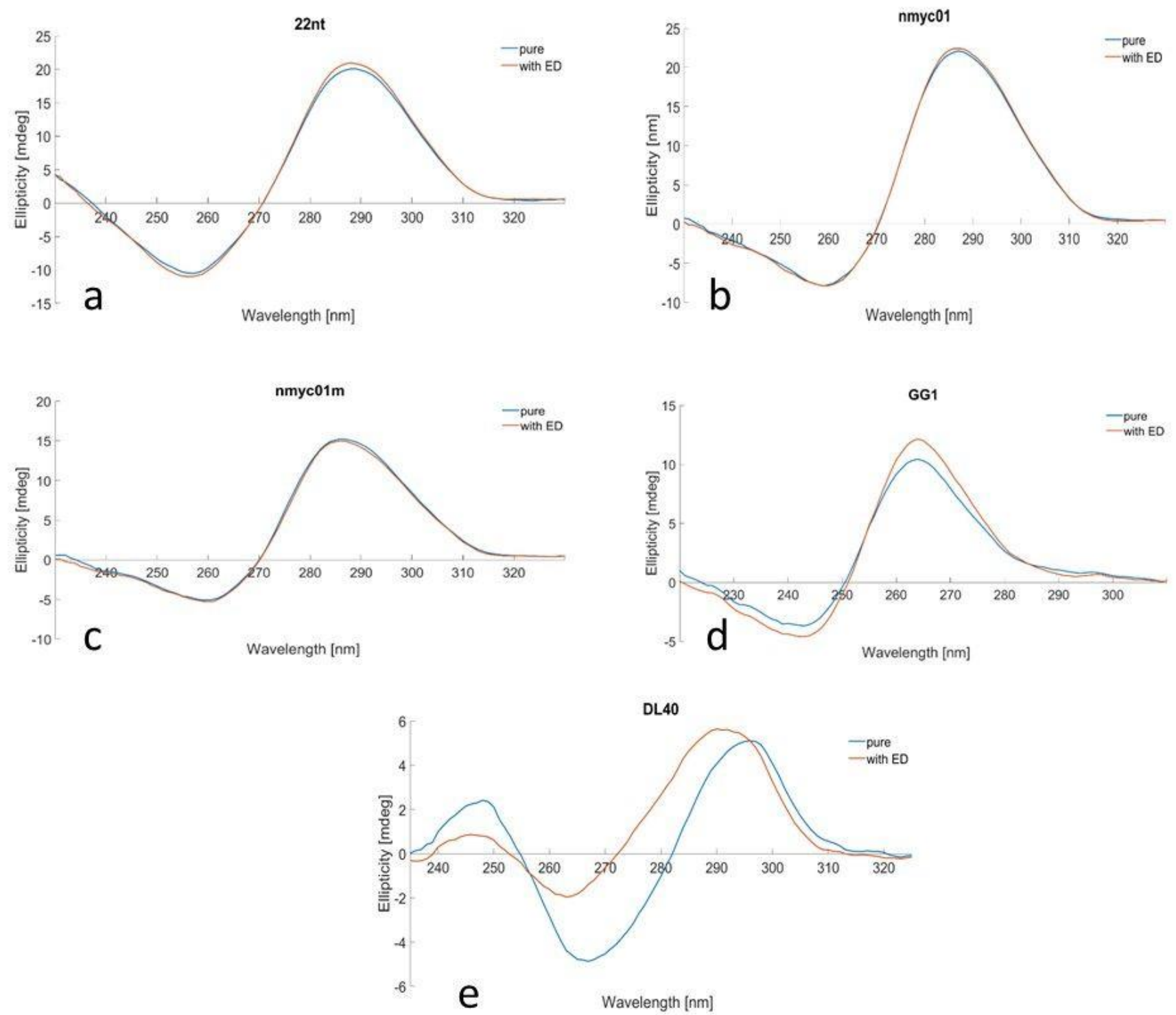

Figure 4. Cont. 


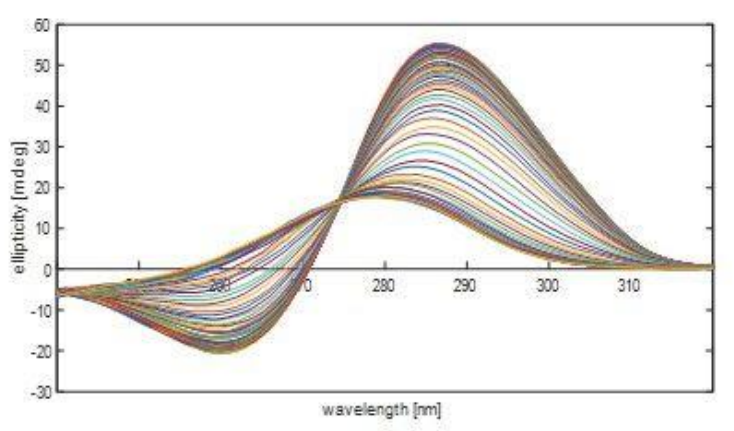

f

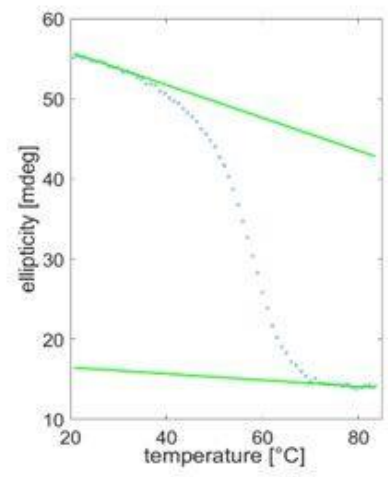

g

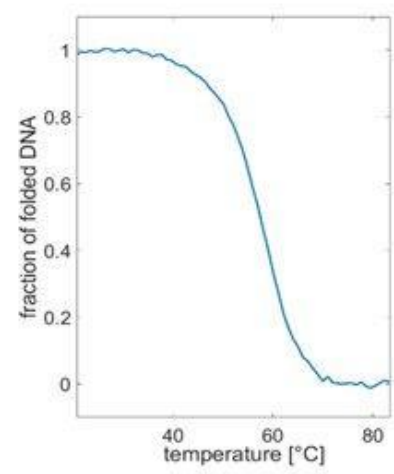

h

Figure 4. $\mathrm{pH}$ 5: CD spectra of 22nt (a), nmyc01 (b), and nmyc01m (c) in the absence (blue) and presence (red) of escholidine in acetic buffer ( $\left.c_{\text {oligo }}=2 \mu \mathrm{M}, \mathrm{t}=20^{\circ} \mathrm{C}\right)$. $\mathrm{pH}$ 7: CD spectra of GG1 (d), and DL40 (e), in the absence (blue) and presence (red) of escholidine at phosphate buffer (coligo $=2 \mu \mathrm{M}, \mathrm{t}=20^{\circ} \mathrm{C}$ ). Temperature dependence: $\mathrm{CD}$ spectra recorded along with the melting experiment of nmyc01 (f), ellipticity trace measured at $287 \mathrm{~nm}(\mathrm{~g})$, and the fraction of folded DNA calculated assuming an intramolecular two-step process $(\mathbf{h})$.

A similar procedure was carried out for guanine-rich sequences (Figure 4). The GG1 oligonucleotide forms a parallel G-quadruplex structure, as denoted by the position of the main CD bands: one positive around $260 \mathrm{~nm}$ and one negative around $240 \mathrm{~nm}$ [35]. The shape of the spectrum of the oligonucleotide alone and with escholidine is the same, only slightly different in intensity. On the other hand, the DL40 oligonucleotide shows a CD spectrum with different features: an intense positive peak around $295 \mathrm{~nm}$, a negative peak around $265 \mathrm{~nm}$, and a small positive peak around $245 \mathrm{~nm}$ [61] are characteristics of antiparallel G-quadruplex sequence. Upon the ligand, evident changes were observed in the CD spectrum, suggesting a specific drug interaction with the G-quadruplex that produced some structural modifications.

CD-monitored melting experiments in the absence and presence of the drug were carried out to gain insight into the potential stabilization of the structures upon interaction with escholidine. Figure 4 shows an example of this procedure.

Table 2 summarizes the melting temperature $(\mathrm{Tm})$ of the DNA structures in the absence and presence of escholidine. In all cases, a two-stage process was considered. This assumption was checked by multivariate analysis of the whole set of spectra measured along with each melting experiment.

Table 2. $\mathrm{T}_{\mathrm{m}}$ values of pure oligonucleotides and mixtures.

\begin{tabular}{cccc}
\hline \multirow{2}{*}{ Oligonucleotide } & \multicolumn{2}{c}{$\mathbf{T}_{\mathbf{m}}\left[{ }^{\circ} \mathbf{C}\right]$} & \multirow{\Delta}{*}{$\mathbf{\Delta} \mathbf{T}_{\mathbf{m}}\left[{ }^{\circ} \mathbf{C}\right]$} \\
\cline { 2 - 3 } & Pure & with ED & \\
\hline GG1 & $48.1 \pm 0.4$ & $49.8 \pm 1.4$ & 1.7 \\
DL40 & $28.8 \pm 0.9$ & $34.0 \pm 0.8$ & 5.2 \\
nmyc01 & $58.1 \pm 0.4$ & $57.8 \pm 1.6$ & -0.3 \\
nmyc01m & $55.8 \pm 0.9$ & $55.2 \pm 1.1$ & -0.6 \\
22nt & $51.5 \pm 0.1$ & $52.2 \pm 0.5$ & 0.7 \\
\hline
\end{tabular}

The most stable structure in terms of the $T_{m}$ value was the G4 structure DL40. In the presence of escholidine (1:4 DNA:ligand ratio), some variations in $T_{m}$ values were observed. In the case of nmyc01, thermal stability was not increased as in the case of the mutated version of this oligonucleotide (nmyc $01 \mathrm{~m}$ ). Additionally, minimal stabilization was observed in the case of the i-motif formed by 22nt, which does not include any WatsonCrick base pair. Overall, this suggests that escholidine does not interact strongly with the i-motif core, i.e., C. $\mathrm{C}^{+}$base pairs that stabilize the structure. 
In the case of the parallel G-quadruplex structure formed by GG1, a slight increase was observed. However, the most significant change can be observed with antiparallel $\operatorname{DL} 40\left(\Delta \mathrm{T}_{\mathrm{m}}=5.2{ }^{\circ} \mathrm{C}\right)$, which agrees with the evident changes observed in the CD spectrum upon adding the ligand.

The thermodynamic analysis allowed the determination of the changes in enthalpy, entropy, and Gibbs free energy associated with each transition, assuming a two-stage process and a constant value of the changes in enthalpy and entropy (Table 3). Considering the uncertainties associated with the determined values of the thermodynamic parameters, the interaction of escholidine with the considered sequences produces minor variations.

Table 3. Thermodynamic parameters for the folding process in the absence and presence of escholidine. These values were determined from the CD-monitored melting experiments assuming a two-state process and null constant values of the changes in enthalpy and entropy through the melting process. The associated uncertainties are $5 \%$ for $\Delta \mathrm{H}$ and $\Delta \mathrm{S}$ and $10 \%$ for $\Delta \mathrm{G}$.

\begin{tabular}{ccccccc}
\hline \multirow{2}{*}{ Oligonucleotide } & \multicolumn{3}{c}{ Pure } & \multicolumn{3}{c}{ with ED } \\
\cline { 2 - 7 } & $\mathbf{\Delta G} \mathbf{( 3 7 )}$ & $\mathbf{\Delta} \mathbf{H}[\mathbf{k c a l} / \mathbf{m o l}]$ & $\boldsymbol{\Delta} \mathbf{S}[\mathbf{c a l} / \mathbf{K} \cdot \mathbf{m o l}]$ & $\boldsymbol{\Delta G} \mathbf{( 3 7 )}$ & $\boldsymbol{\Delta H}[\mathbf{k c a l} / \mathbf{m o l}]$ & $\boldsymbol{\Delta S}[\mathbf{c a l} / \mathbf{K} \cdot \mathbf{m o l}]$ \\
\hline GG1 & -1.4 & -40.8 & -127.1 & -1.7 & -42.5 & -131.5 \\
DL40 & 1.7 & -62.3 & -206.5 & 0.6 & -56.2 & -183.0 \\
nmyc01 & -5.4 & -85.0 & -256.7 & -4.4 & -70.1 & -211.8 \\
nmyc01m & -4.4 & -77.9 & -236.8 & -3.8 & -67.3 & -205.0 \\
22nt & -3.2 & -71.4 & -219.9 & -3.7 & -78.9 & -242.4 \\
\hline
\end{tabular}

\subsection{Fluorescence Titrations}

Fluorescence measurements were performed to determine binding stoichiometries and association constants between escholidine and various oligonucleotide structures. Of the titration, the fluorescence spectra of alkaloid without oligonucleotide were measured. The emission maximum was found to be $330 \mathrm{~nm}$. A wavelength of $285 \mathrm{~nm}$ was used for the excitation of samples. When DNA was added, the fluorescence intensity at $330 \mathrm{~nm}$ decreased. The fluorescence quenching induced by DNA to alkaloid interaction enabled us to calculate stability constants and stoichiometry. Examples of recorded spectra and titration curves are shown in Supplementary Materials. Subsequently, Equispec tool was used for data treatment. Each stoichiometry model was considered according to the smallest sum of squares (Supplementary Materials).

The best-fitting model was usually 4:1 or 5:1 (alkaloid:DNA). Thus, the interaction and stabilization of structures are likely to occur through multiple binding mechanisms at once. The stoichiometry models, as well as the calculated association constants, are collected in Table 4 . When the complexity of the models is omitted, association constants are similar for all studied structures.

Table 4. $\log \mathrm{K}_{\mathrm{a}}$ constants and assumed stoichiometry for escholidine:DNA complex.

\begin{tabular}{ccc}
\hline Oligonucleotide & Stoichiometry & Log $\mathbf{K}_{\mathbf{a}}$ \\
\hline GG1 & $1: 5$ & $22.39 \pm 0.03$ \\
DL40 & $1: 4$ & $18.46 \pm 0.05$ \\
nmyc01 & $1: 4$ & $18.21 \pm 0.17$ \\
nmyc01m & $1: 5$ & $22.61 \pm 0.08$ \\
22nt & $1: 4$ & $17.64 \pm 0.12$ \\
\hline
\end{tabular}

\subsection{NMR Analysis}

Imino protons in the double helix, i-motif, and G-quadruplex structures of DNA are involved in different types of hydrogen bonds, and their chemical shifts in ${ }^{1} \mathrm{H}$ NMR spectra are characteristic for each structure: $12-14$ ppm for Watson-Crick CG and AT base pairs, 15-16 ppm for $\mathrm{C}^{-\mathrm{C}^{+}}$base pairs and 10-12 ppm for G-quartets. 
The spectra of nmyc01, nmyc01m, and 22nt (nucleotide alone) present signals at $15-16 \mathrm{ppm}$, showing the formation of i-motif structures (Figure 5). Some differences between nmyc01 and the mutated sequence nmyc $01 \mathrm{~m}$ can be observed. The spectrum of nmyc01 (Figure 5a) showed very weak signals between 12.5-14 ppm, attributable to Watson-Crick base pairs formation in the TGCA tract, which is not present in the mutated sequence nmyc $01 \mathrm{~m}$. The spectrum of nmyco1m (Figure $5 \mathrm{~b}$ ) showed intense signals at $11 \mathrm{ppm}$, assigned to T.T base pair formation, due to the presence of the TTTT tract that has replaced the TGCA fragment. These base pairs are common in the loop residues connecting C-tracts in i-motif structures [62].

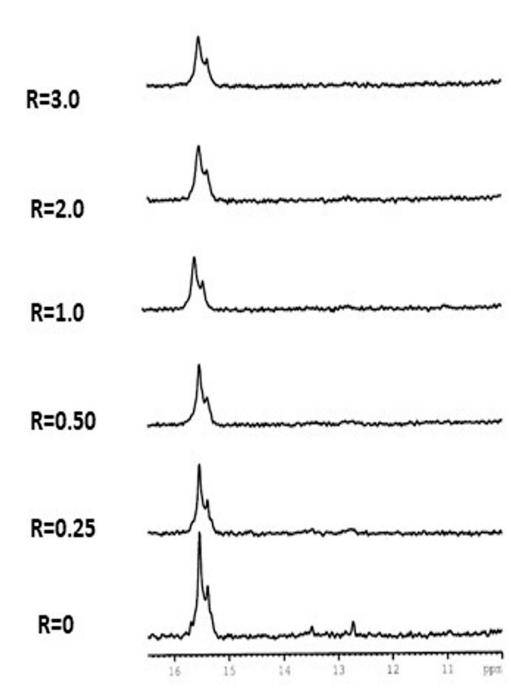

a

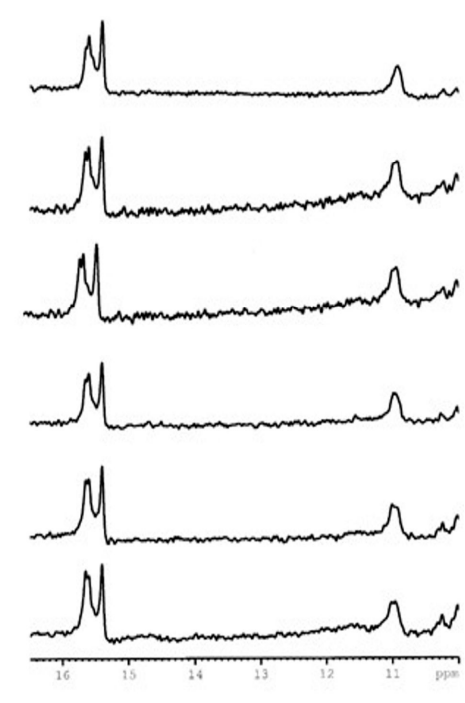

b

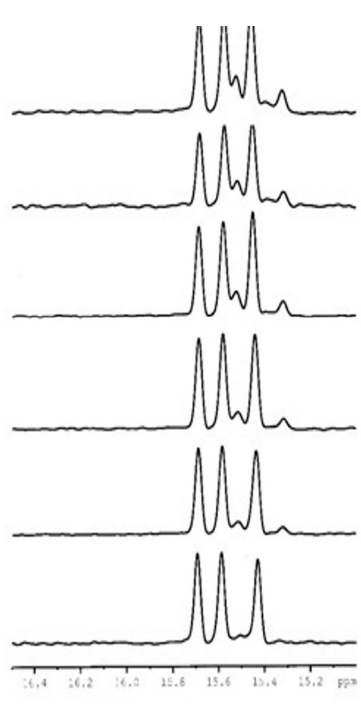

C
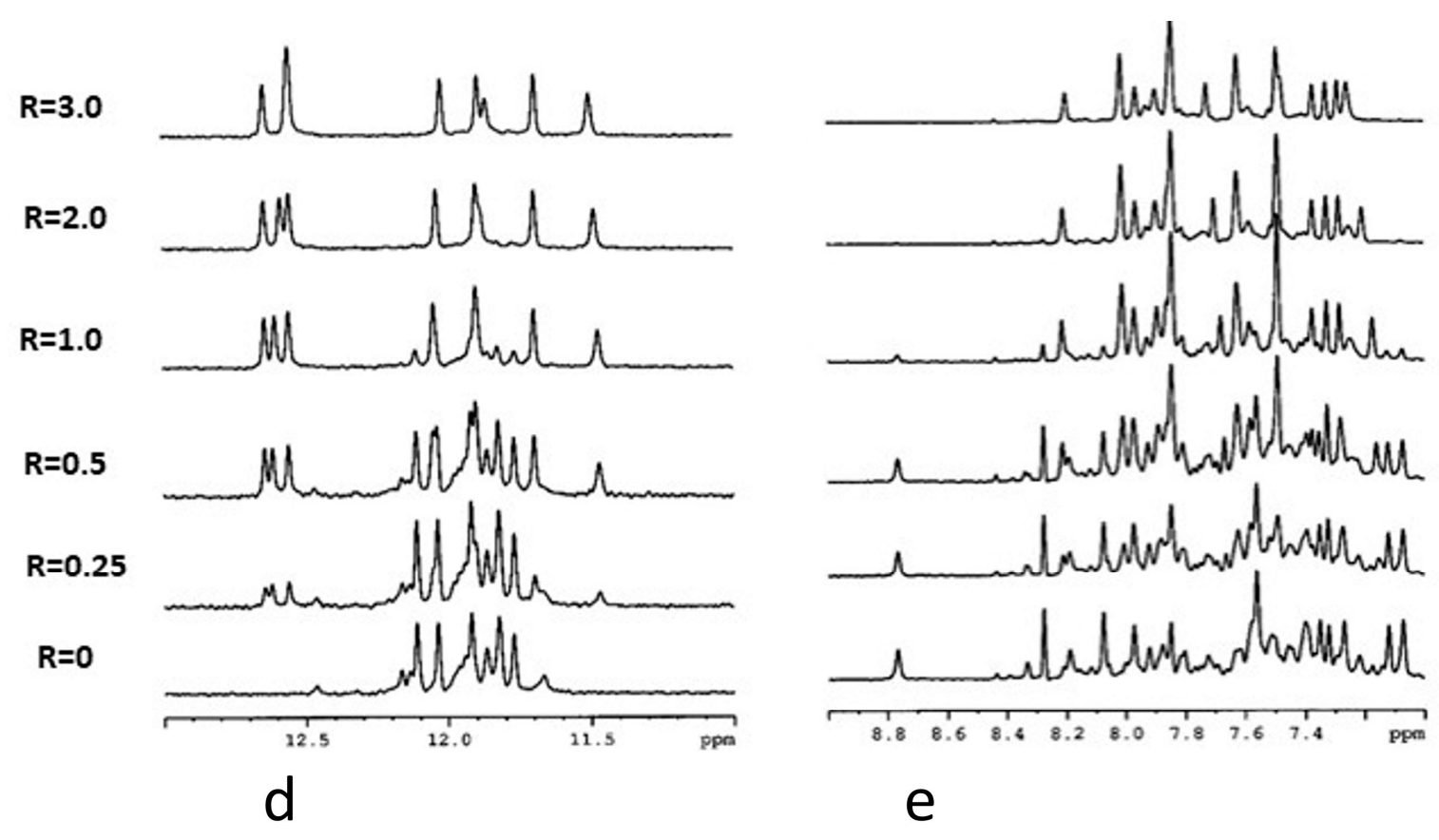

Figure 5. Cont. 


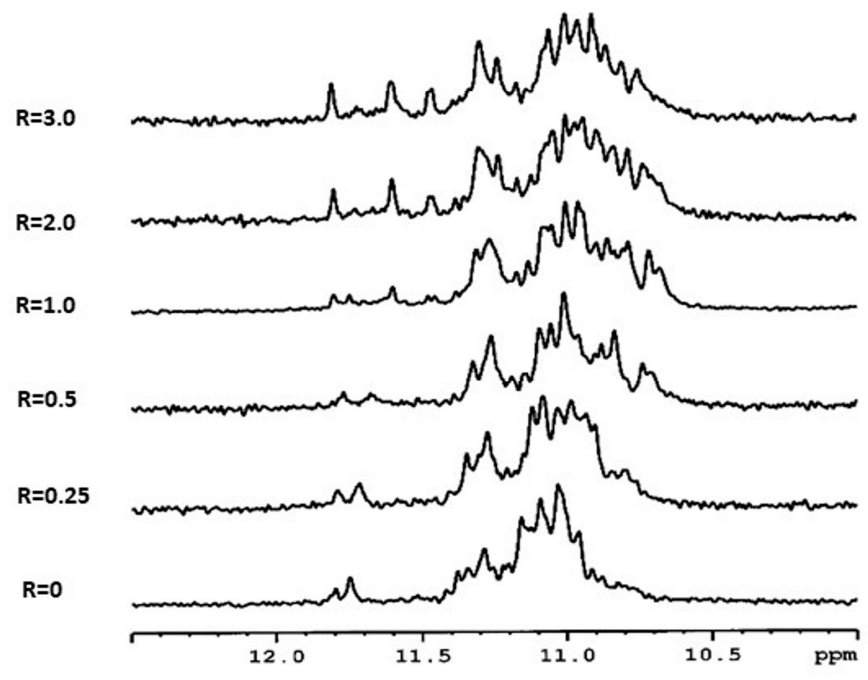

$f$

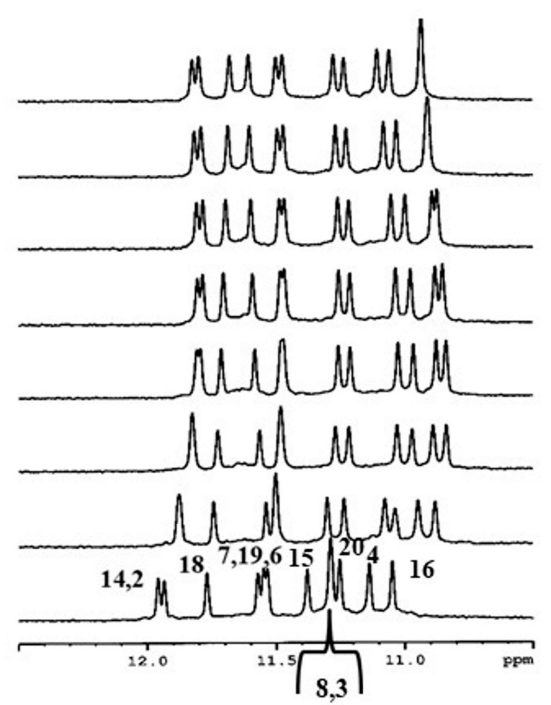

g

Figure 5. Imino proton region of the $1 \mathrm{D}$ NMR titration spectra of nmyc01 (a), nmyc01m (b), and $22 \mathrm{nt}(\mathbf{c})$ at $25^{\circ} \mathrm{C}$ and at different $\mathrm{R}=$ [drug]/[DNA] ratios. Imino protons (d) and aromatic protons (e) regions of the 1D NMR titration spectra of DL40 at $25^{\circ} \mathrm{C}$ and different $\mathrm{R}=(\mathrm{drug}) /(\mathrm{DNA})$ ratios. Imino protons region of the 1D NMR titration spectra of GG1 (f) and ckit21T12T21 (g) at $25^{\circ} \mathrm{C}$ and different $\mathrm{R}=(\mathrm{drug}) /(\mathrm{DNA})$ ratios.

The titration experiment of nmyc01 revealed a slight line broadening of the signals at $15-16 \mathrm{ppm}$, due to the $\mathrm{C}-\mathrm{C}^{+} \mathrm{NH}$ proton pairs, while the weak signals at $12.5-14 \mathrm{ppm}$ decreased and disappeared for $\mathrm{R}=$ (ligand) $/(\mathrm{DNA}=0.25)$ (Figure $5 \mathrm{a})$. This suggests some interaction of escholidine to the i-motif, with the disruption of the Watson-Crick base pairs of the hairpin structure. The same experiment with the mutated sequence cmyc $01 \mathrm{~m}$ did not cause any change in the resonances of the imino protons, suggesting that escholidine neither intercalated nor stacked externally to the cytosine bases (Figure 5b). Upon addition of escholidine to 22nt oligonucleotide, only small insignificant changes in the imino protons of hemiprotonated cytosines occurred (Figure $5 \mathrm{c}$ ).

The structural polymorphism of G-quadruplex structures makes them versatile targets of ligands, consequently stabilizing them. As the interaction of escholidine with $G$ quadruplexes seems to be more promising from CD results, we chose the DL40 for NMR experiments. The spectrum of this oligonucleotide alone showed in our experimental conditions both sharp and broad NH imino signals (Figure $5 \mathrm{~d}$ ). The same behavior is shown by the non-exchangeable aromatic resonances, indicating the conformational heterogeneity of the G-quadruplex (Figure 5e). Upon each addition of escholidine, remarkable changes in the NMR spectra were observed, showing evidence of some interaction. Even at low $\mathrm{R}=0.25$, a new set of imino signals associated with the guanine moieties of the tetrad at $\delta=12.5-12.8 \mathrm{ppm}$ is observed. All the other signals, including the aromatic ones, still appear very crowded at this $R$ ratio. At $R \geq 1.0$, the imino and the aromatic protons region became less complicated, indicating a single folding conformation; thus, some stabilization of the G-quadruplex structure due to the ligand must occur. The resonances of escholidine are too broad and could not be detected. Their broad shape indicated that the ligand can either move in the binding site or bind to different binding sites of the target. For this reason, we decided to examine the ckit2 21 mer, which shows a parallel G-quadruplex structure in comparison with the antiparallel structure of DL40. This nucleotide adopts in $\mathrm{K}^{+}$solution two distinct antiparallel G-quadruplex conformations in slow exchange, forming either a monomeric or a dimeric structure, depending on the concentration of $\mathrm{KCl}[29,30]$. Unfortunately, the simultaneous presence of the two species causes a line 
widening in the signals (Figure $5 \mathrm{a}, \mathrm{R}=0$ ). The addition to escholidine slightly improves the appearance of the spectra, but the binding with the ligand is not sufficient to stabilize one of the two conformations. Thus, the NH imino signals remain very broad (Figure $5 \mathrm{f}$ ).

It was found that the $\mathrm{G}$ to $\mathrm{T}$ mutation at positions 12 and 21 of the above sequence further stabilizes, at low $\mathrm{KCl}$ concentration, the monomeric intramolecular parallel Gquadruplex (ckit2T12T21) [45,54]. In these conditions, the NH imino protons are well resolved, and the addition of escholidine caused changes in the NMR spectrum, even at a low $\mathrm{R}$ ratio $=0.25 / 1.0$ (Figure $5 \mathrm{~g}$ ). During the titration experiment, the presence of the imino protons in 10.8-12.0 ppm indicated that the G-quadruplex structure was maintained. This is confirmed by the assignments of the guanine $\mathrm{NH}$ and $\mathrm{H} 8$ protons, performed through the sequential NOEs interactions of the imino signals and the interresidue NOE connectivity between $\mathrm{NH}$ and $\mathrm{H} 8$ resonances, characteristic of the three tetrads (Table S1). The non-exchangeable proton signals also sharpened, whereas those of escholidine remain very broad and could not be assigned. By increasing the R until a value of 3 , the spectrum did not change significantly. Most of the $\mathrm{NH}$ signals of the external tetrads moved to upfield, but such effect is not equally distributed over the four guanines of each tetrad. Specifically: G2 and G18 NH $(\Delta \delta-0.19 \mathrm{ppm}$ and $-0.14 \mathrm{ppm})$ at the $5^{\prime}$-terminal end, G4 NH $(\Delta \delta-0.22 \mathrm{ppm}) \mathrm{G} 20(\Delta \delta-0.18 \mathrm{ppm})$ and G8 $(\Delta \delta-0.26 \mathrm{ppm})$ at $3^{\prime}$-end (Figure 6 and Table S2). These results indicate that escholidine interacts with the G-quadruplex positioning over the external tetrads but covering only half of the guanine planes. It appears preferentially located over the guanines G2, G18 of the $5^{\prime}$-end, and over the guanines G4 at 3'-end.

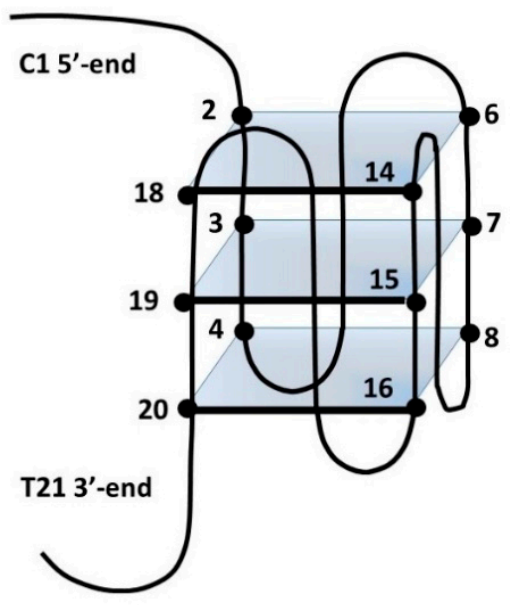

Figure 6. Schematic representation of ckit21T12T21. Numbers refer to the position of bases within this sequence.

\subsection{Molecular Modeling Studies}

The three-dimensional model of the complex between escholidine and DL40, as obtained from the blind molecular docking experiment, is shown in the Figure 7.

No counterions were added to the starting three-dimensional structure of the antiparallel G-quadruplex DL40. Although counterions are known to be stabilizing factors, the experimental structure of the DL40 used in this work appears to self-stabilize even without counterions. For this reason, we decided not to make arbitrary changes to the experimental model of the G-quadruplex DL40.

The ligand rises above the T4 and T20 base pair, forming a $\pi-\pi$ stacking interaction and a cation- $\pi$ interaction with the aromatic rings of T4 and T20, respectively. The T6 nucleotide lies alongside the ligand, resulting in a $\pi-\pi \mathrm{T}$-shaped interaction, which contributes to the overall stability of the complex. Finally, the complex is further stabilized by a hydrogen bond between the $\mathrm{OH}$ group of the ligand and $\mathrm{OP}_{2} \mathrm{~T} 20(2.68 \AA)$. 

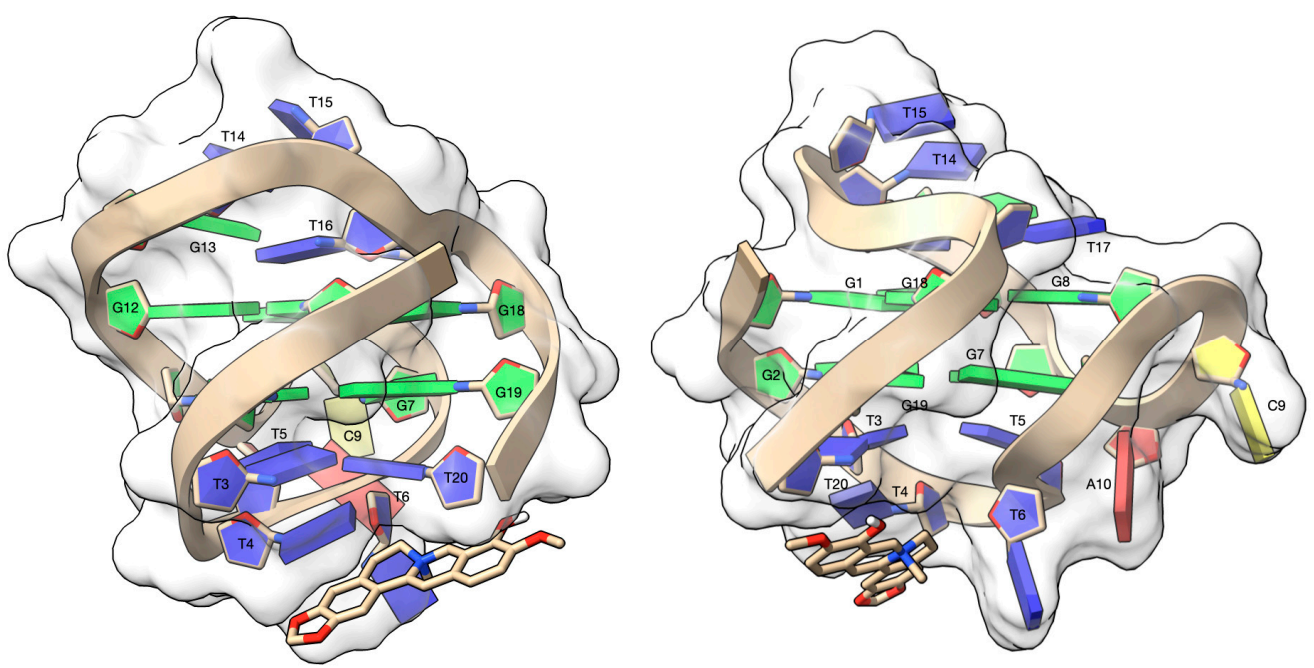

Figure 7. Side views of the complex between escholidine and the DL40 G-quadruplex, as obtained from the molecular docking experiment. The G-quadruplex target is contoured by a ghostly-white solvent accessible surface (SAS) and the nucleotides were depicted as filled rings: adenine in red, cytosine in yellow, guanine in green and thymine in blue. The escholidine alkaloid is represented as van der Waals ( $\mathrm{vdW}$ ) spheres and coloured according to the atom types. The drawing was created by using the Chimera-X software (Resource for Biocomputing, Visualization, and Informatics San Francisco, CA, USA) [63].

\section{Conclusions}

In the framework of a project devoted to the identification of natural alkaloids that could selectively bind to G-quadruplex and i-motif structures, the interaction of escholidine with several guanine- and cytosine-rich sequences prone to form these structures has been studied. This interaction has been characterized by means of fluorescence titrations, melting experiments, and molecular modeling as well as NMR spectroscopy.

Fluorescence spectroscopy, as a highly sensitive method, enabled the detection of the interactions of escholidine with all studied G-quadruplex and i-motif structures through fluorescence quenching. The binding stoichiometry and stability constants were estimated from the fluorescence titration curves. Best fitting models were found to have stoichiometry, similarly to benzo[c]phenatridine alkaloids [40], 1:4 or 1:5. Since the fluorescence spectroscopy is a very sensitive method and can detect even weak changes in the fluorophore (alkaloid) environment; therefore, recorded changes in fluorescence intensities can also reflect non-specific interactions of alkaloid molecules to oligonucleotides.

The CD melting experiments have shown that alkaloid binding does not affect the thermal stability of i-motifs; therefore, interactions previously observed by fluorescence spectroscopy can be assigned as only weak electrostatic interactions.

On the other hand, a certain stabilization was observed for G-quadruplexes, specifically for the antiparallel structure adopted by DL40, being the difference in melting temperature $5.2^{\circ} \mathrm{C}$ in this case. These results are in line with those previously published for alkaloids from the protoberberine group-berberine [44], corysamine, and coptisine [39].

NMR studies provided structural information on the interaction of escholidine with the considered sequences. Hence, for an interaction where the alkaloid does not fully intercalate into the G-quadruplex structure, and being the interaction most likely to go through the external loop, it causes an overall slight stabilization of the structure. Escholidine can be located over the external tetrads but covering only half of the guanine planes. This is proven by the shielding effect on the guanine resonance, which is lower than that of other ligands [38-40]. The interaction with DNA could be considered one of the mechanisms of action of these alkaloids, even if additional mechanisms involving other targets cannot be excluded. 
The discrepancy between fluorescence titration experiments showing higher stoichiometry and other methods showing a 1:1 model can be explained by the strong interaction of one molecule of alkaloid to DNA (main) binding site and several weak and non-specific interactions of three to four alkaloid molecules to oligonucleotide surface. This non-specific interaction can be eventually assigned also as the stacking of alkaloids to each other when only the nearest alkaloid is attached to the oligonucleotide structure.

As the highest affinity to escholidine shows DL40 structure, the three-dimensional model of the complex between alkaloid and DL40 was prepared by means of molecular docking. The $\pi-\pi$ stacking interaction and a cation- $\pi$ interaction with the aromatic rings of $\mathrm{T} 4$ and T20, respectively, were found to be the most stabilizing factors accompanied by a $\pi-\pi$ T-shaped interaction to the T6 nucleotide.

Concerning i-motif structures, NMR studies suggested some interaction of escholidine to the i-motif formed by nmyc01 with the disruption of the Watson-Crick base pairs of the internal hairpin structure. The same experiment with the mutated (myc01m) and 22nt sequences suggested that escholidine neither intercalated nor stacked externally to the cytosine bases. Hence, further research must be carried out to find natural alkaloids that could bind to i-motif structures.

Supplementary Materials: The following are available online at https:/ /www.mdpi.com/article/ 10.3390/biology10121225/s1, Figure S1: CD melting curves of oligonucleotides. Table S1: Interresidue NOE interactions of c-kit21T12T21 in the complex with escholidine, Table S2: Selected ${ }^{1} \mathrm{H}$ chemical shift values for the complex of escholidine with c-kit21T12T21, Figure S2: Example of a titration of escholidine with GG1. Table S3: Stoichimetry model, sum of squares and calculated $\log K$ values for interaction of escholidine with GG1. Figure S3: Dependence of the sum of squares of residuals vs. the DNA:ligand stoichiometry. Figure S4: Example of a titration of escholidine with DL_40. Figure S5: Example of a titration of escholidine with nmyc01. Figure S6: Example of a titration of escholidine with nmyc01m. Figure S7: Example of a titration of escholidine with 22nt.

Author Contributions: Conceptualization, R.G.; methodology, P.J.; software, P.H., R.A.; validation, S.M.; formal analysis, S.M., R.G., P.T.; investigation, P.J., P.H., K.K., S.M., G.B.; resources, P.T., E.T.; data curation, P.J., S.M., R.G.; writing—original draft preparation, E.T., P.T.; writing—review and editing, R.G., P.T.; visualization, R.A.; supervision, E.T., R.G., P.T.; project administration, P.T.; funding acquisition, P.T. All authors have read and agreed to the published version of the manuscript.

Funding: APC was founded by Department of Chemistry, Faculty of Science, Masaryk University.

Institutional Review Board Statement: Not applicable.

Informed Consent Statement: Not applicable.

Data Availability Statement: Data sharing not applicable.

Acknowledgments: CIISB research infrastructure project LM2018127 funded by MEYS CR is gratefully acknowledged for the financial support of the measurements at the CF CEITEC-Biomolecular Interaction and Crystallization. This research was supported GAMU MUNI/A/1192/2020 financed by MŠMT ČR and PIANO DI SOSTEGNO ALLA RICERCA 2020-Linea 2 azione B (DEFENS). This investigation was supported by research grant from the Spanish Ministerio de Ciencia e Innovación (PID2019-107158GB-I00).

Conflicts of Interest: The authors declare no conflict of interest.

\section{References}

1. Rajecky, M.; Slaninova, I.; Mokrisova, P.; Urbanova, J.; Palkovsky, M.; Taborska, E.; Taborsky, P. Alkaloid chelirubine and DNA: Blue and red luminescence. Talanta 2013, 105, 317-319. [CrossRef]

2. Rybakova, S.; Rajecky, M.; Urbanova, J.; Pencikova, K.; Taborska, E.; Gargallo, R.; Taborsky, P. Interaction of oligonucleotides with benzo c phenanthridine alkaloid sanguilutine. Chem. Pap. 2013, 67, 568-572. [CrossRef]

3. Sandor, R.; Slanina, J.; Midlik, A.; Sebrlova, K.; Novotna, L.; Carnecka, M.; Slaninova, I.; Taborsky, P.; Taborska, E.; Pes, O. Sanguinarine is reduced by NADH through a covalent adduct. Phytochemistry 2018, 145, 77-84. [CrossRef] [PubMed]

4. Rajecky, M.; Sebrlova, K.; Mravec, F.; Taborsky, P. Influence of Solvent Polarity and DNA-Binding on Spectral Properties of Quaternary Benzo c phenanthridine Alkaloids. PLoS ONE 2015, 10, e0129925. [CrossRef] 
5. Leitao da-Cunha, E.V.; Fechine, I.M.; Guedes, D.N.; Barbosa-Filho, J.M.; Sobral da Silva, M. Protoberberine Alkaloids. In The Alkaloids: Chemistry and Biology; Cordell, G.A., Ed.; Academic Press: Cambridge, MA, USA, 2005; Volume 62, pp. 1-75.

6. Grycová, L.; Dostál, J.; Marek, R. Quarternary Protoberberine Alkaloids; Elsevier: Amsterdam, The Netherlands, 2007; Volume 68, pp. 150-175.

7. Dostál, J.; Slavík, J. Novější Poznatky o Sanguinarinu a Příbuzných Alkaloidech; Chemické Listy: Praha, Czech Republic, 2000; pp. 15-20.

8. Majidzadeh, H.; Araj-Khodaei, M.; Ghaffari, M.; Torbati, M.; Ezzati Nazhad Dolatabadi, J.; Hamblin, M.R. Nano-based delivery systems for berberine: A modern anti-cancer herbal medicine. Colloids Surf. B Biointerfaces 2020, 194, 111188. [CrossRef]

9. Ponnusamy, L.; Kothandan, G.; Manoharan, R. Berberine and Emodin abrogates breast cancer growth and facilitates apoptosis through inactivation of SIK3-induced mTOR and Akt signaling pathway. Biochim. Biophys. Acta (BBA)—Mol. Basis Dis. 2020, 1866, 165897. [CrossRef]

10. Ma, W.; Zhang, Y.; Yu, M.; Wang, B.; Xu, S.; Zhang, J.; Li, X.; Ye, X. In-vitro and in-vivo anti-breast cancer activity of synergistic effect of berberine and exercise through promoting the apoptosis and immunomodulatory effects. Int. Immunopharmacol. 2020, 87, 106787. [CrossRef]

11. Gu, S.; Song, X.; Xie, R.; Ouyang, C.; Xie, L.; Li, Q.; Su, T.; Xu, M.; Xu, T.; Huang, D.; et al. Berberine inhibits cancer cells growth by suppressing fatty acid synthesis and biogenesis of extracellular vesicles. Life Sci. 2020, 257, 118122. [CrossRef]

12. Chudík, S.; Marek, R.; Seckárová, P.; Necas, M.; Dostál, J.; Slavík, J. Revision of the structure of escholidine. J. Nat. Prod. 2006, 69, 954-956. [CrossRef] [PubMed]

13. Slavík, J.; Dolejš, L.; Sedmera, P. Alkaloids of the Papaveraceae, XLIV. Quaternary alkaloids from roots of three Escholtzia species and from the aerial part of Hunnemannia fumariaefolia SWEET: Constitution of escholidine. Collect. Czechoslov. Chem. Commun. 1970, 35, 2597-2612. [CrossRef]

14. Schäfer, H.L.; Schäfer, H.; Schneider, W.; Elstner, E.F. Sedative action of extract combinations of Eschscholtzia californica and Corydalis cava. Arzneim.-Forsch. 1995, 45, 124-126.

15. Rolland, A.; Fleurentin, J.; Lanhers, M.C.; Younos, C.; Misslin, R.; Mortier, F.; Pelt, J.M. Behavioural effects of the American traditional plant Eschscholzia californica: Sedative and anxiolytic properties. Planta Med. 1991, 57, 212-216. [CrossRef] [PubMed]

16. Jain, L.; Tripathi, M.; Pandey, V.B. Alkaloids of Eschscholtzia californica. Planta Med. 1996, 62, 188. [CrossRef]

17. Bochman, M.L.; Paeschke, K.; Zakian, V.A. DNA secondary structures: Stability and function of G-quadruplex structures. Nat. Rev. Genet. 2012, 13, 770-780. [CrossRef]

18. Takahashi, S.; Sugimoto, N. Quantitative Analysis of Stall of Replicating DNA Polymerase by G-Quadruplex Formation. In G-Quadruplex Nucleic Acids: Methods and Protocols; Yang, D., Lin, C., Eds.; Springer: New York, NY, USA, 2019 ; pp. $257-274$.

19. Abou Assi, H.; Garavís, M.; González, C.; Damha, M.J. i-Motif DNA: Structural features and significance to cell biology. Nucleic Acids Res. 2018, 46, 8038-8056. [CrossRef]

20. Spiegel, J.; Adhikari, S.; Balasubramanian, S. The Structure and Function of DNA G-Quadruplexes. Trends Chem. 2020, 2, 123-136. [CrossRef] [PubMed]

21. Blackburn, G.M. Nucleic Acids in Chemistry and Biology, 3rd ed.; Royal Society of Chemistry: Cambridge, UK, 2006.

22. Khandelwal, P.; Panchal, S.C.; Radha, P.K.; Hosur, R.V. Solution structure and dynamics of GCN4 cognate DNA: NMR investigations. Nucleic Acids Res. 2001, 29, 499-505. [CrossRef]

23. Phan, A.T.; Mergny, J.L. Human telomeric DNA: G-quadruplex, i-motif and watson-crick double helix. Nucleic Acids Res. 2002, 30, 4618-4625. [CrossRef]

24. Neidle, S. 2-The Building-Blocks of DNA and RNA. In Principles of Nucleic Acid Structure; Academic Press: New York, NY, USA, 2008; pp. 20-37.

25. Burge, S.; Parkinson, G.N.; Hazel, P.; Todd, A.K.; Neidle, S. Quadruplex DNA: Sequence, topology and structure. Nucleic Acids Res. 2006, 34, 5402-5415. [CrossRef]

26. Vojtylová, T.; Dospivová, D.; Třísková, O.; Pilařová, I.; Lubal, P.; Farková, M.; Trnková, L.; Táborský, P. Spectroscopic study of protonation of oligonucleotides containing adenine and cytosine. Chem. Pap. 2009, 63, 731-737. [CrossRef]

27. Dzatko, S.; Krafcikova, M.; Hänsel-Hertsch, R.; Fessl, T.; Fiala, R.; Loja, T.; Krafcik, D.; Mergny, J.-L.; Foldynova-Trantirkova, S.; Trantirek, L. Evaluation of the Stability of DNA i-Motifs in the Nuclei of Living Mammalian Cells. Angew. Chem. Int. Ed. 2018, 57, 2165-2169. [CrossRef]

28. Alba, J.J.; Sadurní, A.; Gargallo, R. Nucleic Acid i-Motif Structures in Analytical Chemistry. Crit. Rev. Anal. Chem. 2016, 46, 443-454. [CrossRef]

29. Jin, K.S.; Shin, S.R.; Ahn, B.; Rho, Y.; Kim, S.J.; Ree, M. pH-Dependent Structures of an i-Motif DNA in Solution. J. Phys. Chem. B 2009, 113, 1852-1856. [CrossRef]

30. Wright, E.P.; Huppert, J.L.; Waller, Z.A.E. Identification of multiple genomic DNA sequences which form i-motif structures at neutral pH. Nucleic Acids Res. 2017, 45, 2951-2959. [CrossRef] [PubMed]

31. Gurung, S.P.; Schwarz, C.; Hall, J.P.; Cardin, C.J.; Brazier, J.A. The importance of loop length on the stability of i-motif structures. Chem. Commun. 2015, 51, 5630-5632. [CrossRef]

32. Brooks, T.A.; Kendrick, S.; Hurley, L. Making sense of G-quadruplex and i-motif functions in oncogene promoters. FEBS J. 2010, 277, 3459-3469. [CrossRef] 
33. Leroy, J.-L.; Guéron, M.; Mergny, J.-L.; Hélène, C. Intramolecular folding of a fragment of the cytosine-rich strand of telomeric DNA into an i-motif. Nucleic Acids Res. 1994, 22, 1600-1606. [CrossRef] [PubMed]

34. Khan, N.; Aviñó, A.; Tauler, R.; González, C.; Eritja, R.; Gargallo, R. Solution equilibria of the i-motif-forming region upstream of the B-cell lymphoma-2 P1 promoter. Biochimie 2007, 89, 1562-1572. [CrossRef]

35. Simonsson, T.; Pribylova, M.; Vorlickova, M. A Nuclease Hypersensitive Element in the Human c-myc Promoter Adopts Several Distinct i-Tetraplex Structures. Biochem. Biophys. Res. Commun. 2000, 278, 158-166. [CrossRef] [PubMed]

36. Brazier, J.A.; Shah, A.; Brown, G.D. I-Motif formation in gene promoters: Unusually stable formation in sequences complementary to known G-quadruplexes. Chem. Commun. 2012, 48, 10739-10741. [CrossRef]

37. Zeraati, M.; Langley, D.B.; Schofield, P.; Moye, A.L.; Rouet, R.; Hughes, W.E.; Bryan, T.M.; Dinger, M.E.; Christ, D. I-motif DNA structures are formed in the nuclei of human cells. Nat. Chem. 2018, 10, 631-637. [CrossRef]

38. Feng, L.; Dong, Z.; Tao, D.; Zhang, Y.; Liu, Z. The acidic tumor microenvironment: A target for smart cancer nano-theranostics. Nat. Sci. Rev. 2018, 5, 269-286. [CrossRef]

39. Jarosova, P.; Sandor, R.; Slaninkova, A.; Vido, M.; Pes, O.; Taborsky, P. Quaternary protoberberine alkaloids and their interactions with DNA. Chem. Pap. 2019, 73, 2965-2973. [CrossRef]

40. Jarosova, P.; Paroulek, P.; Rajecky, M.; Rajecka, V.; Taborska, E.; Eritja, R.; Aviñó, A.; Mazzini, S.; Gargallo, R.; Taborsky, P. Naturally occurring quaternary benzo[c]phenanthridine alkaloids selectively stabilize G-quadruplexes. Pchys. Chem. Chem. Phys. 2018, 20, 21772-21782. [CrossRef]

41. Adamcik, J.; Valle, F.; Witz, G.; Rechendorff, K.; Dietler, G. The promotion of secondary structures in single-stranded DNA by drugs that bind to duplex DNA: An atomic force microscopy study. Nanotechnology 2008, 19, 384016. [CrossRef] [PubMed]

42. Wright, E.P.; Day, H.A.; Ibrahim, A.M.; Kumar, J.; Boswell, L.J.E.; Huguin, C.; Stevenson, C.E.M.; Pors, K.; Waller, Z.A.E. Mitoxantrone and Analogues Bind and Stabilize i-Motif Forming DNA Sequences. Sci. Rep. 2016, 6, 39456. [CrossRef] [PubMed]

43. Mazzini, S.; Bellucci, M.C.; Mondelli, R. Mode of binding of the cytotoxic alkaloid berberine with the double helix oligonucleotide d(AAGAATTCTT)2. Bioorganic Med. Chem. 2003, 11, 505-514. [CrossRef]

44. Gargallo, R.; Aviñó, A.; Eritja, R.; Jarosova, P.; Mazzini, S.; Scaglioni, L.; Taborsky, P. Study of alkaloid berberine and its interaction with the human telomeric i-motif DNA structure. Spectrochim. Acta Part A Mol. Biomol. Spectrosc. 2021, 248, 119185. [CrossRef]

45. Fernando, H.; Reszka, A.P.; Huppert, J.; Ladame, S.; Rankin, S.; Venkitaraman, A.R.; Neidle, S.; Balasubramanian, S. A Conserved Quadruplex Motif Located in a Transcription Activation Site of the Human c-kit Oncogene. Biochemistry 2006, 45, 7854-7860. [CrossRef]

46. Kuryavyi, V.; Majumdar, A.; Shallop, A.; Chernichenko, N.; Skripkin, E.; Jones, R.; Patel, D.J. A double chain reversal loop and two diagonal loops define the architecture of unimolecular DNA quadruplex containing a pair of stacked $G($ syn) $\cdot G($ syn $) \cdot G($ anti) $\cdot G($ anti) tetrads flanked by a G.(T-T) triad and a T·T·T triple1. J. Mol. Biol. 2001, 310, 181-194. [CrossRef]

47. Benabou, S.; Ferreira, R.; Aviñó, A.; González, C.; Lyonnais, S.; Solà, M.; Eritja, R.; Jaumot, J.; Gargallo, R. Solution equilibria of cytosine- and guanine-rich sequences near the promoter region of the n-myc gene that contain stable hairpins within lateral loops. Biochim. Biophys. Acta (BBA)—Gen. Subj. 2014, 1840, 41-52. [CrossRef] [PubMed]

48. Bell, E.; Chen, L.; Liu, T.; Marshall, G.M.; Lunec, J.; Tweddle, D.A. MYCN oncoprotein targets and their therapeutic potential. Cancer Lett. 2010, 293, 144-157. [CrossRef]

49. Mergny, J.-L.; Riou, J.-F.; Mailliet, P.; Teulade-Fichou, M.-P.; Gilson, E. Natural and pharmacological regulation of telomerase. Nucleic Acids Res. 2002, 30, 839-865. [CrossRef] [PubMed]

50. Datta, B.; Armitage, B.A. Hybridization of PNA to Structured DNA Targets: Quadruplex Invasion and the Overhang Effect. J. Am. Chem. Soc. 2001, 123, 9612-9619. [CrossRef]

51. Puglisi, J.D.; Tinoco, I. Absorbency melting curves of RNA. Methods Enzymol. 1989, 180, 304-325.

52. Breslauer, K.J. Extracting thermodynamic data from equilibrium melting curves for oligonucleotide order-disorder transitions. Energetics Biol. Macromol. 1995, 259, 221-242.

53. Dyson, R.M.; Kaderli, S.; Lawrance, G.A.; Maeder, M. Second order global analysis: The evaluation of series of spectrophotometric titrations for improved determination of equilibrium constants. Anal. Chim. Acta 1997, 353, 381-393. [CrossRef]

54. Kuryavyi, V.; Phan, A.T.; Patel, D.J. Solution structures of all parallel-stranded monomeric and dimeric G-quadruplex scaffolds of the human c-kit2 promoter. Nucleic Acids Res. 2010, 38, 6757-6773. [CrossRef]

55. Moraca, F.; Amato, J.; Ortuso, F.; Artese, A.; Pagano, B.; Novellino, E.; Alcaro, S.; Parrinello, M.; Limongelli, V. Ligand binding to telomeric G-quadruplex DNA investigated by funnel-metadynamics simulations. Proc. Natl. Acad. Sci. USA 2017, 114, E2136-E2145. [CrossRef]

56. Morris, G.M.; Goodsell, D.S.; Halliday, R.S.; Huey, R.; Hart, W.E.; Belew, R.K.; Olson, A.J. Automated docking using a Lamarckian genetic algorithm and an empirical binding free energy function. J. Comput. Chem. 1998, 19, 1639-1662. [CrossRef]

57. Morris, G.M.; Huey, R.; Lindstrom, W.; Sanner, M.F.; Belew, R.K.; Goodsell, D.S.; Olson, A.J. AutoDock4 and AutoDockTools4: Automated Docking with Selective Receptor Flexibility. J. Comput. Chem. 2009, 30, 2785-2791. [CrossRef]

58. Gasteiger, J.; Marsili, M. Iterative Partial Equalization of Orbital Electronegativity-A Rapid Access to Atomic Charges. Tetrahedron 1980, 36, 3219-3228. [CrossRef]

59. Sanner, M.F. Python: A programming language for software integration and development. J. Mol. Graph. Model. 1999, $17,57-61$.

60. Goddard, T.D.; Huang, C.C.; Meng, E.C.; Pettersen, E.F.; Couch, G.S.; Morris, J.H.; Ferrin, T.E. UCSF ChimeraX: Meeting modern challenges in visualization and analysis. Protein Sci. 2018, 27, 14-25. [CrossRef] [PubMed] 
61. Ambrus, A.; Chen, D.; Dai, J.; Bialis, T.; Jones, R.A.; Yang, D. Human telomeric sequence forms a hybrid-type intramolecular G-quadruplex structure with mixed parallel/antiparallel strands in potassium solution. Nucleic Acids Res. 2006, 34, 2723-2735. [CrossRef]

62. Benabou, S.; Aviñó, A.; Lyonnais, S.; González, C.; Eritja, R.; De Juan, A.; Gargallo, R. i-motif structures in long cytosine-rich sequences found upstream of the promoter region of the SMARCA4 gene. Biochimie 2017, 140, 20-33. [CrossRef] [PubMed]

63. Kim, S.; Chen, J.; Cheng, T.J.; Gindulyte, A.; He, J.; He, S.Q.; Li, Q.L.; Shoemaker, B.A.; Thiessen, P.A.; Yu, B.; et al. PubChem in 2021: New data content and improved web interfaces. Nucleic Acids Res. 2021, 49, D1388-D1395. [CrossRef] [PubMed] 